\title{
THE LINKAGE OF NATURAL DISASTER RISK AND POVERTY
}

\author{
H.M.D Subodini Herath \\ School of Social Work, National Institute of Social Development, Nawala, Sri Lanka
}

\begin{abstract}
Natural Disasters are broadly predictable to affect inexplicably the poorest in a community, as they have relatively higher sensitivity to disaster events compared with communities of higher development status. Constant events increase the vulnerability and risk of the poor to disasters, increasing poverty levels such that many households often are unable to break out of the poverty cycle. Medium to longer term impacts of natural disasters at the national level also challenge development progress towards reducing poverty, possibly creating situations which place a boundary between urban and rural communities keeping them in an immense risk. The linkage between natural disasters and poverty is a global phenomenon which has long term impacts on lives and livelihood of people worldwide. This study focuses on the linkage between flood disaster risk and poverty which leads people to settle in disaster prone areas. Moreover, the study gives special attention to poverty eradication techniques to reduce disaster risks. The study was conducted in Pattiwla North GN Division under Biyagama Divisional Secretariat in Gampaha District. The primary data was collected through case studies and the secondary data was collected through various sources. The study proves the direct link and co-relationship between disaster risk and poverty. The findings of the research study reveal that disaster risk and poverty has a direct linkage. As a recommendation, Disaster Risk Management should be introduced from the grass root level to minimise risk factors of poor people.
\end{abstract}

Keywords: Vulnerability, Poverty, Disaster Prone Areas, Poverty Eradication Techniques, Disaster Risk

\section{Introduction}

Disaster incorporates the multidimensional socioeconomic and political issues including the physical characteristics, social structure with socioeconomic capability, and political perception. The magnitude of any disaster creates the risks of disaster vulnerability in different ways that apply to different groups. When people face the risks of disaster vulnerability, they face the decrease of capability, which creates the multi-dimensional socioeconomic and political crises. Materially, this involves damage/loss of physical assets, infrastructure, domestic assets, and agricultural output. Non-materially, social relations, status-role linkages, norms, values, crime, grievance, conflicts and the rhythm of everyday organized social and cultural life are disturbed. The major victims are usually those who are marginalized: the poor and the destitute, women, and children, who have the lack of capability on the context of unequal access to resources.

Disasters are felt most often, hardest and deepest, by those countries, communities and individuals that can least cope. Evidence suggests there is an urgent need for both strategic and practical steps to address the relationship between poverty and disaster, at global, national and local levels. This is important for balanced development between the urban and rural poor. Increasingly, exposure to risk grows daily in both urban and rural contexts. Natural disasters are related to the risks of economic vulnerability, which reflects in the everyday lives of local people. Poverty is an ex-post measure which refers to being deprived of basic levels of economic wellbeing and human development. It also characterized as the deprivation of capabilities. Vulnerability, on the other hand, is an ex-ante measure of household's wellbeing and concerning about the future poor. In both pre disaster and post disaster phases the poor are more vulnerable than any other groups. Virtually all disaster studies show that 
wealthiest of the population either survive the disaster unaffected or are able to recover quickly. Poverty is both a driver and consequence of disasters, and the processes that further disaster risk related poverty are permeated with inequality. Risk as a function of hazard and vulnerability, a relationship that is frequently illustrated with the following formula, although the association is not strictly arithmetic:

\section{Risk = hazard $\mathbf{x}$ vulnerability}

Poverty is a vicious cycle of which traps and depletes future generations' potential. Children born into poverty will grow up in poverty and give birth to children who are brought into the cycle of poverty. Natural Disasters only deepen the poverty within a family or community and makes it harder to break out of the cycle. Without reduction of economic and lifestyle impact of natural disasters in poverty affected areas all means of funding for getting people out of poverty is ineffective. Funds would be spent rebuilding from a disaster and getting to a livable standard instead of directly spent on the underlying problem; Poverty. Poverty itself can physically, mentally and emotionally drain people and the resources and money they possess, therefore, natural disasters adding to this cycle can only mean struggle and hardships which has to be minimized for the betterment of all people.

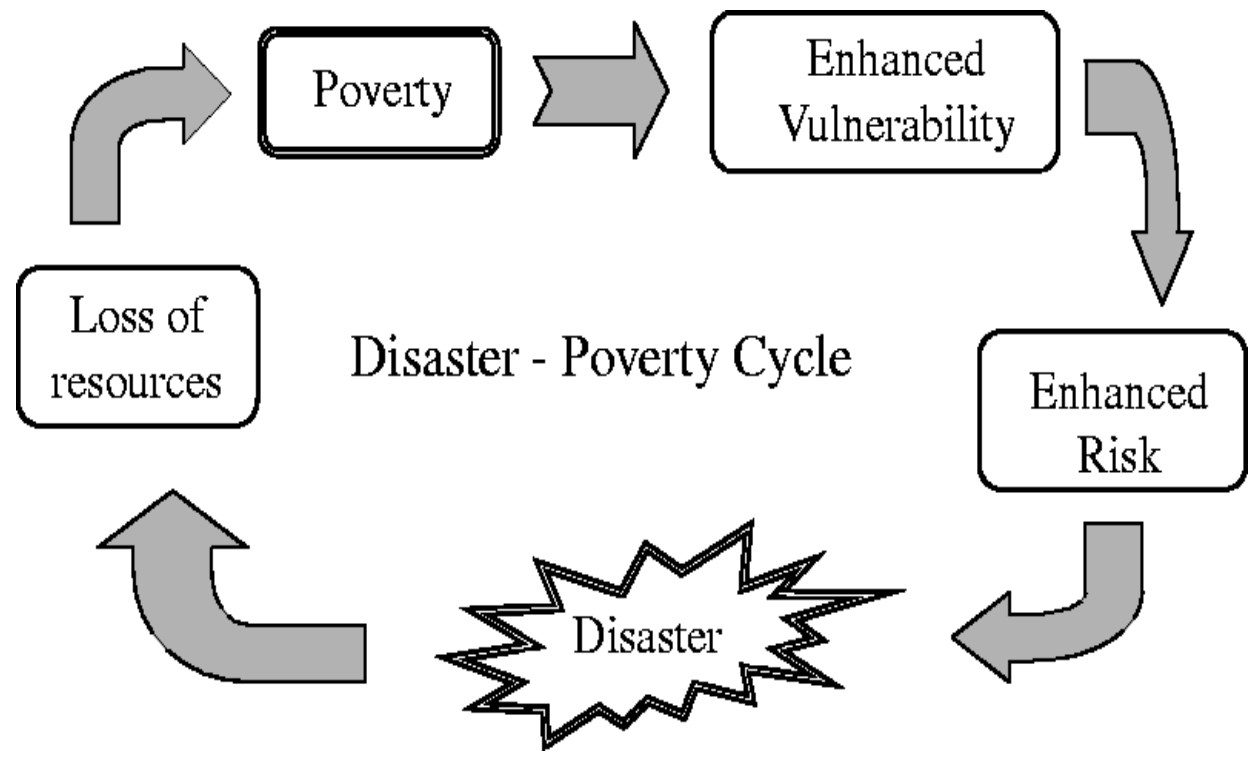

Figure 01: Disaster - Poverty Cycle (Source: Human Wellbeing - Natural disasters)

As the above figure 01 explains there is a direct inter-connection between disasters and poverty. Vulnerability is one of the defining components of disaster risk. Poverty is both a driver and consequence of disasters, and the processes that further disaster risk related poverty are permeated with inequality. This study was conducted to identify the linkage between flood disaster risk and poverty which leads people to settle in disaster prone areas. Moreover, the study gives special attention to poverty eradication techniques to reduce disaster risks. The study was conducted in Pattiwla North GN Division under Biyagama Divisional Secretariat in Gampaha District. The main objective of this study is to identify the linkage between flood disaster risk and poverty. The specific objectives of this study are to understand the risk factors and poverty eradication strategies and minimizing the loopholes of implementation of National Disaster Management Policy. This study which aims to examine the trends and patterns in extensive risk and of the interactive links between risk and poverty will provide useful insights into the relationship between disaster risk and poverty, if any, that will help policy makers to improve the effectiveness of policies adopted in reducing poverty and mitigating disaster impacts on poverty. 


\section{Methodology}

Across the broad spectrum of disasters, poverty generally makes people vulnerable to the impact of disasters. The most important single influence on the impact of disaster is poverty. All other factors could be lessened if the affected population not also limited by poverty. Floods are one of the recurrent disasters to Sri Lanka due to inter monsoonal seasons. Poverty is one of the major causal factors for people to settle in flood prone river banks. The total population in this Grama Niladhari division is 3489 and among that there are 1512 females and 1977 males. The total numbers of flood affected families are 34 and there are total numbers of 16 Samurdhi beneficiaries among the flood affected families. The study used qualitative case study method as the primary data collection method with semi structured interviews. Through convenient purposive sampling method most vulnerable 06 participants (03 males and 03 females) were selected from the total flood affected population according to their low income level rate after checking the records from the total flood affected population of Grama Niladhari. Books and reports were used as secondary data collection method. All research participants' consent was obtained.

Table 01: Description of the sample

\begin{tabular}{|c|c|c|c|c|}
\hline $\begin{array}{l}\text { Name (Changed the } \\
\text { real names) }\end{array}$ & Job & $\begin{array}{l}\text { Average Monthly } \\
\text { Income }\end{array}$ & $\begin{array}{l}\text { Number of Family } \\
\text { Members }\end{array}$ & $\begin{array}{l}\text { Condition of the } \\
\text { present house }\end{array}$ \\
\hline 1.Kamal & Daily Wage Worker & Rs: 15,000 & $\begin{array}{l}4 \text { (One Daughter, } \\
\text { One Son and Wife - } \\
\text { house wife) }\end{array}$ & Temporary house \\
\hline 2. Saman & $\begin{array}{l}\text { Construction } \\
\text { Worker }\end{array}$ & Rs: 20,000 & $\begin{array}{l}5 \text { (Two Sons, One } \\
\text { Daughter and Wife- } \\
\text { house wife) }\end{array}$ & Half build house \\
\hline 3. Asanga & Security Guard & Rs. 20,000 & $\begin{array}{l}4 \text { (Two Daughters } \\
\text { and Wife-house } \\
\text { wife) }\end{array}$ & Half build house \\
\hline 4.Seetha & House Maid & Rs: 15,000 & $\begin{array}{l}3 \text { (One Son and } \\
\text { Husband-Disabled) }\end{array}$ & Half build house \\
\hline 5. Anoma & Cleaner & Rs: 20,000 & $\begin{array}{l}4 \text { (Two Sons and } \\
\text { Husband- not } \\
\text { engaged in a job) }\end{array}$ & Temporary house \\
\hline 6. Renu & House Maid & Rs: 15,000 & $\begin{array}{l}4 \text { (One Daughter, } \\
\text { One Son and } \\
\text { Husband- not } \\
\text { engaged in a job) }\end{array}$ & Temporary house \\
\hline
\end{tabular}

The Table 01 explains about the sample details and the real names of all the participants have changed due to confidentiality and ethical reasons. The study consists of participants from different ethnic groups and both female and male participants to ensure the ethnic and gender equality. The qualitative data was analysed through a step by step process identifying emerging themes clustering those by concepts. The emerging themes were labelled with participant's as well as researcher's words.All the case studies are discussed hereunder. 


\section{Case Studies}

\section{Case 01}

Kamal is a daily wage worker and lives with his daughter, son and his wife. He is living in a temporary house and his average monthly income is Rs.15, 000. His wife is not doing any job and she a housewife. Kamal is not eligible to be a Samurdhi beneficiary due to his temporary residency. They are living in a temporary shelter near the river bank and he and his family are constant victims of yearly flood disaster. Kamal has already taken a personal loan and he has to pay monthly debt for that. His monthly income was not sufficient enough to save money to build a permanent house.

\section{Case 02}

Saman is a construction worker and there are overall five members within the family consists of two sons, one daughter his wife and himself. His average monthly income is Rs.20, 000 and he lives in a half built house. His wife is suffering from various health issues and therefore she is unable to do a job. He had to arrange money for his elder daughter's puberty ceremony and therefore he had to take a personal loan. Presently he is paying debt for his personal loan. Saman is also living near the river bank and they are suffering yearly due to the flood disaster. Since he has three children his monthly income is insufficient to handle the overall expenses.

\section{Case 03}

Asanga is a security guard and he lives with his wife and two daughters. His average monthly income is Rs.20, 000 and he lives in a half built house. His wife is not engaged in any job and he is the only bread winner in the family. He is addicted to alcohol. Therefore he spends lots of his monthly income on his alcohol consumption. He never uses to save money and has taken a personal loan to build his present half built house. Since he is addicted to alcohol, he never had any future plan to complete his half built house.

\section{Case 04}

Seetha is a housemaid and live with her husband and son. Her average monthly income is Rs: 15,000 and she use to live in a half built house. Her husband is not engaged in any job due to physical disability. Their family use to live in the river bank and her salary was not sufficient for their monthly expenses. She is unable to spend much money on her son's education due to paying debts on her personal loans. She even had to mortgage her house due to insufficient income.

\section{Case 05}

Anoma is a cleaner and she lives with her two sons and her husband. She lives in a temporary house and her average monthly income is Rs.20,000. Since she lives in a temporary house she is unable to prove her residency and get Samurdhi benefits. She is the only breadwinner in her family and since her husband is suffering from heart disease he is unable to engage in any job. She is a victim of yearly floods since she lives near the near the river bank. She had to take a personal loan for her husband's bypass surgery. Her monthly income is insufficient since her monthly expenditure is quite high.

\section{Case 06}

Renu is a housemaid and she lives with her daughter, son and her husband. Her average monthly income is Rs: 15,000 and she lives in a temporary house. Her husband is paralysed and due to that he is unable to engage in any job. Renu is the single breadwinner of the family. Since she lives in a temporary house she is unable to 
prove her residency and get Samurdhi benefits. Renu has to take personal loan since her monthly salary is not sufficient for her husband's medical needs and her children's educational needs.

\section{Results and Findings}

According to the findings, all the participants were belong to low income families and therefore, all of them had issues with their monthly expenses. All the participants were engaged in jobs but no one is doing a job in government sector. Therefore there is no job security and there is only one person who is earning money in their families.Many a times they were asked to leave their place due to disaster risk and vulnerability but they were unable to shift due to their low income. Some of the participant's narrative quotes reveals the difficulty and challenges faced by them which leads them to stay in the same disaster prone area rather than migrating to a safer place." Miss we don't have anywhere to go rather than living in this place. We are struggling to live with our monthly income." This narrative quote reveals that due to their low income, even though they are willing to move to a safer place they were unable to do that. Three participants were having around six perches of their own land plots where their half built houses. Whereas the other three participants even don't have their own land plots living in temporary houses. Due to low income and insecure accommodation social and environmental vulnerability is comparatively high among this target group.Since all the participants are living near the river bank all of them are victims of yearly flood disaster.Some of them are not getting even Samurdhi benefits since they are unable to prove their permanent residence ship. One of the narrative quotes of participant as, "We don't even get Samurdhi, because we don't have our own land. We are victimized yearly because of floods. We know that living in here, there is a big risk but we are helpless" reveals the difficulty they are facing due to not even eligible for getting Samurdhi benefit. The findings of the study revealed that flood impacts leads to reduced accessibility to human basic needs which results into household poverty. Reduced access to income also reduces the household's ability to fully recover from the flood destructions before the next flood. Because of this, most households are trapped in cyclic poverty. Some households are not able to rebuild their houses because of insufficient income exposing them to poor living conditions.

\section{Conclusion}

Natural disaster risk and poverty has a direct inter-relationship. Due to poverty people tend to live in disaster prone areas and ultimately they will be vulnerable towards various risk factors. Urban poor people suffering most with natural disasters and they are at a great risk. Poverty and vulnerability generally associated with each other and it leads to enhance the environmental vulnerability and social vulnerability. Thus it reveals that poverty and vulnerability causes social inequality and socio-economic deprivation in flood disaster situations in Sri Lanka. Due to frequent economic losses caused by floods, the residents are trapped in cyclic poverty with no escape route. The households cannot fully recover from the effects of floods due to limited income and frequent destructions. Instead, their development process is always pushed back each year.

\section{Recommendations}

Disaster risk management essentially aims at a reduction of vulnerability. Therefore, Disaster Risk Management should be introduced from the grass root level to minimise risk factors of poor people. Rehabilitation and resettlement programmes should be introduced to minimise vulnerability of poor. Moreover, Disaster Management policy should be reformulated to address the issues of poor people and their vulnerability of living in unsafe areas. There should be a proper policy implication to provide safer locations for the poor vulnerable people who live in disaster prone unsafe areas. Introduce flood insurance through government and nongovernment partnerships and Flood Plain Management.Rehabilitation and resettlement programmes should be introduced to minimise vulnerability of poor.Social protection, social insurance or micro credit schemes for the landless households might motivate vulnerable people to start small scale business or farming. Drainage systems should be improved and Flood insurance and Flood Plain Management should be introduced and implemented in an effective manner. 


\section{References}

PardeepS, Alka D, Uma M, Disaster Migration Experiences and Reflections: PHI Learning Private Limited; 2010

Perera V, Disasters and Disaster Management: S.Godage\& Sons; 2014

Thilakasiri L.S, Water,Land and People in Climate Change: A Stamford Lake Publications; 2016

Douglas I, Climate Change, Flooding and Flood Security in South Asia: Springer; 2009

Freeman, P. K, Managing Disaster Risk in Emerging Economies: Journal of Disaster Risk Reduction; 2000

Mirza Q.M.M, Dixit A, \&Nishat A, Natural Hazards: Journal of Environment; 2003

Wisner B, Blaikie P, Cannon T, \& Davis I, At Risk - Natural Hazards, People's Vulnerability and Disasters; London and New York: Routledge; 2004 